\title{
EL CANCIONERO DE LA GUERRA CIVIL. PROPAGANDA Y CONTRAPROPAGANDA SONORA.
}

\section{SPANISH CIVIL WAR SONGS. SOUND PROPAGANDA AND AGAINST-PROPAGANDA}

\author{
AUTORA \\ Ma Teresa Piñeiro Otero. \\ Universidad de Vigo. Pontevedra (España). \\ m.terepo@gmail.com
}

\section{RESUMEN}

Durante la Guerra Civil española de 1936 fueron muchas las canciones e himnos que sonaron tanto en el frente como en la retaguardia. Ambos bandos utilizaron dichas composiciones para vehicular su ideología entre una población con alto grado de analfabetismo.

Esta función propagandística de himnos y canciones se complementó con otro tipo de letrillas populares, en muchos casos variaciones de composiciones identificativas de un determinado colectivo, utilizadas para denostar al enemigo.

\section{PALABRAS CLAVE}

Canciones - Guerra Civil- Propaganda 


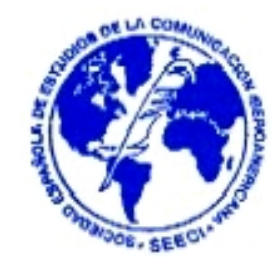

\section{ABSTRACT}

During the 1936 Spanish Civil War were many songs and hymns that sounded both the front and the rear. Both sides used such compositions to transmit their ideology in a population with high illiteracy.

The propaganda function of hymns and songs are supplemented with other popular letrillas, in many cases variations in identifying compositions of a particular group, used to insult the enemy.

\section{KEY WORDS}

Songs- Spanish Civil War- Propaganda

\section{ÍNDICE}

1. Introducción

2. La canción como instrumento de propaganda.

3. Tipología de composiciones de ambos bandos de la Guerra Civil.

3.1. Las canciones de autor

3.2. Los himnos

4. El cancionero de la Guerra Civil. Principales líneas temáticas.

4.1. Canciones de regimientos, divisiones y otras agrupaciones.

4.2. Canciones de contenido político.

4.3. Canciones de nacionalistas.

4.4. Canciones patrióticas.

4.5. Canciones que relatan acontecimientos bélicos.

4.6. Canciones con personajes.

4.7. Canciones de contenido cotidiano. 
4.8. Canciones de contenido amoroso.

4.9. Canciones de contenido religioso.

4.10. Canciones sobre las madres.

4.11. Canciones sobre las mujeres.

4.12. Canciones sobre las muerte

5. La contrapropaganda.

6. A modo de conclusión.

7. Bibliografía

8. Webgrafía

\section{Introducción}

Durante la Guerra Civil española de 1936 fueron numerosas las canciones e himnos que sonaron tanto en el frente como en la retaguardia. Ambos bandos hacían uso de la canción con dos objetivos fundamentales: con fines propagandísticos entre una población con un alto grado de analfabetismo y como un mecanismo para levantar la moral a los combatientes y civiles víctimas de la guerra.

Muchos de estos himnos y canciones habían sido "heredados" de movimientos y situaciones históricas anteriores (tal es el caso canciones como Trágala en el Bando Republicano o la Marcha Real en el Nacional), otros se correspondían con canciones de autor (Los Campesinos- Antonio Aparicio), pero en su mayoría eran composiciones espontáneas que surgían en un momento dado y se quedaban en una zona concreta o se llegaban a extender y a popularizar. 


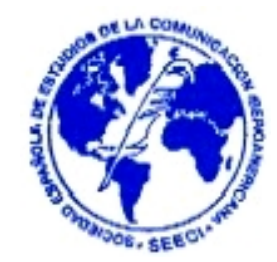

En este contexto es más que probable que algunas canciones se hayan perdido con sus protagonistas y otras hayan sufrido variaciones o simplificaciones de estrofas, por lo que el mensaje que ha llegado hasta hoy en día puede diferir respecto al de aquel momento concreto.

Con la intención de realizar una aproximación a las canciones de la Guerra Civil desde la perspectiva de su función propagandística, se ha llevado a cabo una clasificación de las mismas en función de su origen y temática. Clasificación que se ha efectuado a partir del análisis de contenido de alrededor de trescientas composiciones de ambos bandos (entre himnos, canciones, variaciones recogidas en cancioneros y coplillas populares).

Estas composiciones fueron recopiladas a partir de fuentes bibliográficas, fonotecas web y testimonios orales; tres tipos de fuentes que se han ido complementando y completando a lo largo del trabajo.

\section{La canción como instrumento de propaganda}

La propaganda es un tipo de comunicación que se fundamenta en la emoción al tiempo que estimula aquellos sentimientos ya existentes en el público al que se dirige. Siguiendo Jean Marie Domenach: "la propaganda toma de la poesía la seducción del ritmo, el prestigio del verbo e incluso la violencia de las imágenes" (Domenach, 1963, p.16).

Precisamente esta utilización de la palabra, del ritmo y de las imágenes se puede encontrar en muchas de las manifestaciones de la propaganda política. Entre dichas manifestaciones destacan las canciones por contar con un ritmo, cadencia y por utilizar palabras con una gran carga evocadora.. 


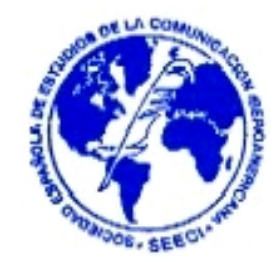

La canción (el ensalzamiento de unas ideas por medio de la palabra y la música) como propaganda, ha sido utilizada a lo largo de la historia como un medio de dar a conocer, hacer entender y propagar con facilidad personajes, hechos históricos, 0 determinadas reivindicaciones.

Entre las potencialidades que presenta el uso de la canción como elemento propagandístico destacan la posibilidad de difundir ideas en comunidades con una gran tasa de analfabetismo, la utilización de la música como reclamo o el alto grado de recuerdo de las palabras ligadas a determinadas melodías. Unas potencialidades que favorecieron su utilización por los diversos movimientos populares como arma política.

Si se parte del hecho de que la población española del siglo XIX y principios del XX contaba con un alto índice de analfabetismo y que se encontraba dispersa por un territorio orográficamente complejo, se pude comprender la relevancia política que alcanzaron las canciones.

En este ámbito, las letras y músicas se convirtieron en una forma eficaz para extender unas determinadas ideas a un núcleo importante de población, que no tendría fácil acceso a otro tipo de expresión propagandística.

Muchos de los movimientos liberales, e incluso otros más conservadores, se hicieran entender por la población a ritmo de coplas, seguidillas, chotis, valses, habaneras y otros tantos ritmos populares.

Otra cuestión es la respuesta popular, de aceptación o rechazo, a una determinada situación socio-política o a un hecho histórico ${ }^{1}$. En estos casos la canción es un

\footnotetext{
${ }^{1}$ Canciones populares como el romance de Alfonso XII suponen la aceptación, por parte del pueblo español, de un hecho concreto. En este caso a la Restauración Borbónica.
} 


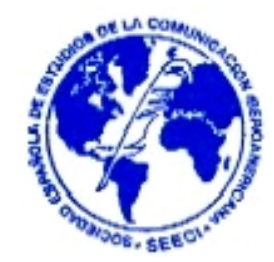

medidor de la opinión pública ante algún cambio (o ante la ausencia del mismo). Este tipo de canción tiene un valor propagandístico doble: el de extender un sentimiento de un pequeño grupo de personas a una colectividad, y el de dar a conocer un estado de ánimo de una comunidad concreta.

Dado que en las filas de uno u otro bando había contendientes cuya adhesión respondía más a circunstancias causales que ideológicas, era frecuente que las canciones asumiesen un papel adoctrinador. De hecho ambos bandos utilizaron diversos tipos de composiciones como poderosos acicates tanto en el frente como en la retaguardia.

Al tiempo que la moral de la población comenzaba a decaer por la situación de sitio y escasez que se vivía, republicanos y nacionales comenzaron a levantar los ánimos con las canciones propagandísticas de las batallas ganadas o de las acciones heroicas llevadas a cabo.

"Como las canciones en tiempos de guerra tiene un marcado sentido propagandístico, rara vez -sólo en contadas ocasiones, tales como el desencantado lamento: 'pobresitos militares...', etc.- nos hablarán de los reveses; sí, en abundancia, de los éxitos bélicos" (Díaz Viana, 1986, p. 44).

\footnotetext{
De los árboles frutales,

me gusta el melocotón;

y de los reyes de España

don Alfonso de Borbón

¿Dónde vas Alfonso XII.

dónde vas triste de ti? (...)
}

Alfonso XII y la relación con su primera mujer fueron mitificados por el folclore popular inspirando numerosas canciones y coplas. Cfr. Gil, B. (1964). Cancionero infantil (antología). Taurus. Madrid. 


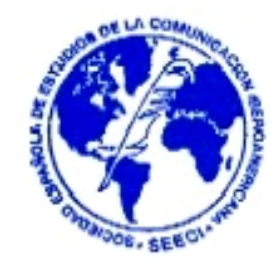

Finalmente resulta destacable la posibilidad que tienen las canciones de estar presente en cualquier momento y lugar. Tanto en el fragor de las trincheras como en los tiempos de distracción ${ }^{2}$ en el frente, en momentos de ilusión o de duda, en soledad o compañía, la canción está siempre aguijoneando la mente de los que la escuchan y cantan.

\section{Tipología de composiciones de ambos bandos de la Guerra}

\section{Civil.}

Durante la Guerra Civil se cantaron diversas composiciones con fines propagandísticos, entendiendo como tales aquellas canciones que, por su contenido, forma o trayectoria histórica, política y social están vinculadas a una ideología concreta.

Atendiendo al origen y difusión se pueden señalar, siguiendo a Díaz de Viana (1986), tres tipos de composiciones: la canción tradicional (ya existente en el folclore), la canción popular (conocida y cantada por una gran colectividad) y la canción culta (aquélla que tiene una música y métrica cuidada y que, a menudo, son composiciones de autores conocidos). Esta división que hace Díaz de Viana para clasificar las Canciones de la Guerra Civil no es una agrupación cerrada sino que puede incorporar matices.

En efecto, muchas de las canciones tradicionales cambiaron sus letras para adaptarse a uno u otro bando (por ejemplo Si me quieres escribir o Carrasclás); otras, consideradas populares al inicio de la contienda eran de autor en su origen e,

\footnotetext{
${ }^{2}$ Las visitas de las mujeres al frente “(...) en ocasiones servían para un propósito más frívolo como para distraer a los soldados con canciones y bailes" (Nash, 1999, p. 175).
} 


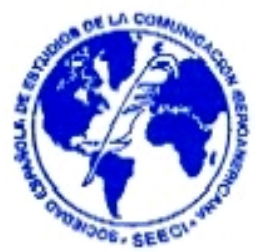

inclusive, algunas de las letras vinculadas a un autor concreto provenían de la tradición oral ${ }^{3}$.

Atendiendo la primera clasificación, de Luis Díaz de Viana, se puede realizar una segunda división dentro del apartado de canción culta (o semiculta). División que incluiría dos tipos de composiciones que fueron comunes a ambos bandos de la Guerra Civil: las canciones de autor y los himnos.

\subsection{Las canciones de autor.}

Las canciones propias de la Guerra Civil, compuestas para uno u otro bando durante la contienda (o inmediatamente después), pueden caracterizar y diferenciar a ambos bandos según el tipo de autoría.

Pese a que Republicanos y Nacionales solían tener en sus cancioneros ambos tipos de composiciones, las de autor y las colectivas ${ }^{4}$, cada una de las fórmulas tuvo mayor desarrollo en un bando concreto.

Entre las canciones recopiladas del Bando Nacional destaca la presencia de un gran número de composiciones de origen culto o semiculto, en su mayoría de autor

\footnotetext{
${ }^{3}$ Es el caso de Los cuatro muleros, canción popular recogida por Federico García Lorca. Desde finales del S.XIX existieron numerosos movimientos culturales y artísticos interesados por el folclore, la antropología y la tradición popular. Poco antes de comenzar la Guerra Civil, había una serie de intelectuales que habían contribuido a "rescatar" lo tradicional (Rodríguez Puértolas, 2001).

${ }^{4}$ El calificativo "colectivas" se aplicará en este estudio a aquellas composiciones populares, habitualmente romances debido a su facilidad de recuerdo y a que su particular rima (asonante) facilita su transformación.

El dieciocho de julio
en el patio de un convento
el partido comunista
fundó el Quinto Regimiento.
}

Fragmento de El Quinto Regimiento, es una adaptación popular de dos canciones tradicionales E/ Vito, con el estribillo de LoS Contrabandistas de Ronda. 


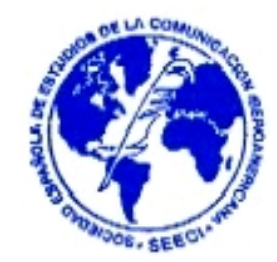

reconocido, sobre las que predominan aquellas vinculadas a la Falange ${ }^{5}$. Sus letras suelen responder a métricas más complejas, que con frecuencia combinan diferentes tipos de versos, además de rimas más cuidadas ${ }^{6}$. Unas canciones que terminaron por extenderse a toda la población como símbolos de la ideología de los vencedores.

La mayoría de estas composiciones presentan un ritmo militarizado (es el caso de Camisa Azun reflejo de la organización castrense de este bando. En sus letras, existen una serie de ideas recurrentes (el amanecer, el sol, Isabel y Fernando...) sobre las que se sustentaban algunos de los fundamentos ideológicos de los llamados nacionales.

En el Bando Republicano, por el contrario, fueron más frecuentes las canciones populares y sus adaptaciones a acontecimientos próximos (batallas, hechos históricos, personajes...) que las canciones de autor. A pesar de que sí existían numerosas composiciones y letras atribuidas a autores concretos.

\footnotetext{
${ }^{5}$ Durante este estudio se han recopilado un total de 37 composiciones de la Falange anteriores a 1939. Cfr. Bullón de Mendoza, 2000: Díaz de Viana, 1986; o los cancioneros de http://www.unamu.org/musica/española/espanola.htm (última consulta 08-022005); http://www.rumbos.net/cancionero (última consulta 08-02-2005); http://www.querracivil1996.galeon.com/canciones (última consulta 11-02-2005).

${ }^{6}$ Sin embargo también son frecuentes otras composiciones más populares como ésta recogida por Bullón de Mendoza y De Diego, 2000, p. 234
}

$$
\begin{gathered}
\text { En el sector del Jarama } \\
\text { allí hay muchos cañoneros } \\
\text { ataques todos los días } \\
\text { con tanques y con morteros }
\end{gathered}
$$

Composiciones que se valieron, en numerosas ocasiones, de músicas populares como este ejemplo que los mismos autores recogen sobre la base de Vivir na Coruña (p.233), canción popular gallega

$$
\begin{gathered}
\text { Eu xa fun a Asturias } \\
\text { fun a combatir } \\
\text { e vin como os roxos } \\
\text { botan a fuxir }
\end{gathered}
$$




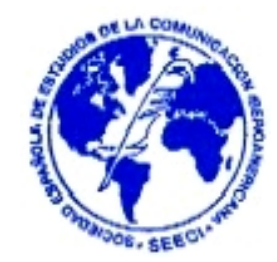

“(..) los propios combatientes recitaban su canciones, que no firmaban, para sus compañeros; con megáfonos las hacían llegar hasta las líneas enemigas, o bien por la radio, o por medio de octavillas arrojadas desde aviones en territorio enemigo (...) Aquella poesía anónima era totalmente popular, coplas elementales y de reminiscencias folcklóricas tradicionales" (Rodríguez Puértolas, 1979, pág. 19)

De hecho, la causa republicana movilizó a escritores e intelectuales que, como Ferico García Lorca, Rafael Alberti o Miguel Hernández, fueron los creadores de numerosas canciones de este bando. Unas composiciones que solían presentar una forma y estructura similar a aquellas canciones de carácter tradicional, como fruto del "neopopularismo" al que se adscribieron algunos de estos autores como García Lorca ${ }^{7}$.

En este bando las expresiones populares (entendidas como las manifestaciones del pueblo) fueron más frecuentes y, con éstas, un estilo directo en la enunciación de los mensajes propagandísticos en las letras de las canciones, escapando del simbolismo del Bando Nacional.

\section{En la plaza de mi pueblo \\ dijo el jornalero al amo \\ nuestros hijos nacerán \\ con el puño levantado ${ }^{8}$}

\footnotetext{
${ }^{7}$ Este poeta, además de recoger canciones tradicionales, hacía composiciones muy similares a las de largo arraigo en la cultura popular Cfr. García Lorca, F. (1994). Romancero Gitano. Madrid, Cátedra.

${ }^{8}$ Fragmento de En la plaza de mi pueblo
} 


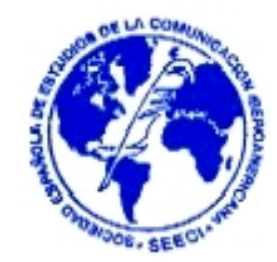

Muchas canciones se valieron de la música e incluso de los estribillos de composiciones tradicionales para renovar su letra al servicio de la causa. Unas melodías conocidas que servían de apoyo a letras sencillas y fácilmente memorables.

$$
\begin{gathered}
\text { ¿Anda jaleo, jaleo! } \\
\text { silba la locomotora } \\
\text { y Franco se va a paseo }{ }^{9}
\end{gathered}
$$

Algunas de ellas, inclusive, permitían improvisar la letra a medida que se cantaban por lo que, además de hacer conocidas algunas de las composiciones más ingeniosas, permitían innovaciones constantes. El ejemplo más destacable de este tipo de canciones es el Carrasclás, usado como un juego de improvisación de letras. Una ejemplo, recogido por Martín Patino (1971) es el siguiente:

\section{Me he metido voluntario porque prefiero la guerra a tenerla todos los días con mi mujer y mi suegra.}

Además de las variaciones de canciones populares, el cancionero republicano incluyó otro tipo de composiciones conocidas que, pese a su origen culto, su adopción por una parte importante de la población las llevó a ser consideradas canciones populares.

\subsection{Los himnos.}

En los cancioneros nacionales y republicanos se pueden encontrar diversas tipologías de himnos, identificadores de los diferentes colectivos presentes en cada bando. Algunos de estos himnos, anteriores a la contienda, cobraron valor durante la Guerra

\footnotetext{
${ }^{9}$ Fragmento de El tren blindado, una adaptación de la canción tradicional Los Contrabandistas de Ronda.
} 


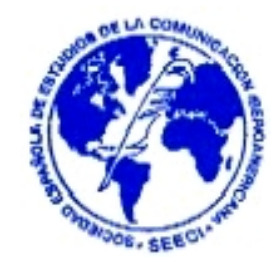

Civil; otros fueron compuestos durante el conflicto bélico en busca de establecer una composición sonora representativa que hiciese las veces de aglutinante en unos bandos heterogéneos.

Los himnos suelen tener un carácter simbólico, en un tono habitualmente elevado, con el que ensalzan los valores del grupo al que representan. Estas composiciones, cargadas de recursos estilísticos, son

\begin{abstract}
“(...) en casi su totalidad obras de autor, no siempre por que su autor sea conocido - no siempre lo es- sino, fundamentalmente por su estilo y función. Su estilo, ampuloso(...) denota a las claras que no son canciones que hayan brotado espontáneamente. Han surgido con una finalidad muy concreta, con una utilidad determinada $y$, por tanto, a pesar de sus pretendidos altos vuelos, se resienten de un claro utilitarismo (...)" (Díaz de Viana, 1986, p. 122)
\end{abstract}

Los himnos también son un elemento distintivo de determinados colectivos, más restringidos, como el militar. En efecto, dentro de la organización castrense resultaba habitual que cada uno de los cuerpos del ejército contase con un himno o una marcha propia, conocida y cantada por todos sus miembros.

Del ejército contaban con un himno o una marcha propia, conocida por todos sus miembros ${ }^{10}$.

\footnotetext{
10 Durante la Guerra Civil se actualizaron y crearon letras para alguno de estos himnos militares en busca de la expresividad y emotividad que poseen las composiciones letradas. Por esta razón también se crearon diversos textos para el himno de España (la Marcha real o Marcha de granaderos), que no llegaron a consolidarse. La más famosa de ellas fue la de José María Pemán. "El efecto de estas estrofas [del himno español] al cantarse resulta bastante ininteligible y, quizá por ello (...) no se haya popularizado demasiado."(Díaz de Viana, 1986, p.134).
} 


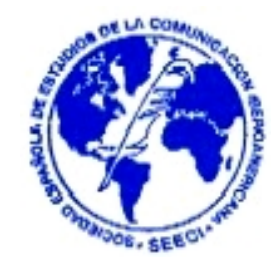

Si se parte del hecho de que el Bando Nacional estaba encabezado por una jerarquía militar que se reflejaba en la estructura del mismo, no resulta extraño que fuese precisamente en este bando donde los himnos adquirieron mayor relevancia.

Precisamente un himno particular, el Cara al Sol, se convirtió en el símbolo sonoro del Bando Nacional y del Franquismo ${ }^{11}$. E, incluso, en los días de la guerra, cuando el Cara al so/ estaba restringido al ámbito de la Falange, se utilizó un himno de la legión como identificador de los sublevados ${ }^{12}$.

Además de los himnos militares y el Cara al Sol, el conjunto de himnos del Bando Nacional se nutrió durante la contienda de otros himnos representativos de los grupos de lo componían: el Oriamendi carlista ${ }^{13}$, y los numerosos himnos de la Falange ${ }^{14}$ que surgieron a finales de la guerra.

En el Bando Republicano la situación era diferente; si bien este movimiento contaba con diversos himnos, ninguno de ellos tuvo la trascendencia del Cara al Sol como composición distintiva. No obstante hubo diversas iniciativas para crear un himno distintivo que nunca llegaron a cuajar.

\footnotetext{
${ }^{11}$ Declarado canto nacional por el Decreto del 27 de febrero de 1937, junto al Oriamendi y el Himno de la Legión.

12 Soy valiente y leal legionario

soy soldado de brava Legión.

pesa en mi alma doliente calvario

que en el fuego busca redención
}

Fragmento del Himno de la Legión de E. Guillén. http://www.unamu.org/musica/española/espanola.htm (última consulta 08$\underline{02-2005)}$.

${ }^{13}$ Que adaptaba los versos "se ha de conseguir/ que venga el Rey de España la la Corte de Madrid" a la situación concreta "se ha de conseguir/ que los boinas rojas/ entren en Madrid" .

${ }^{14}$ La labor de creación de himnos de la Falange fue muy prolífica, como su creación de canciones, a finales de la Guerra Civil y durante la década de los 40. De esta época son los himnos a las banderas de la Falange, por ejemplo, tendencia inaugurada con la aparición del Himno a la Bandera Gallega de la Falange (1936). http://www.rumbos.net/cancionero (última consulta 0802-2005). 


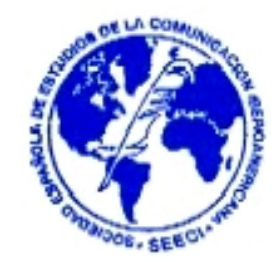

"En el año 1937 la Dirección General de Bellas Artes del Ministerio de Instrucción Pública abrió un concurso para premiar canciones de guerra, entre la que seleccionaría aquellas que tuvieran, a la vez que un carácter popular, una cierta dignidad literaria y musical. Se presentaron 117, de las que solo 6, Uníos hermanos proletarios, Canto a la flota republicana, Venguemos a los caídos, Himno, Canto nocturno en las trincheras y Nueva humanidad, fueron seleccionadas". ${ }^{15}$

Cada una de las ideologías presentes en el Bando Republicano tenía uno o varios himnos distintivos como La Internacional para los comunistas (aunque también contaba con una letra anarquista) o $A$ las barricadas para los anarquistas; además de éstos había otros derivados de movimientos liberales anteriores como el Himno de Riego.

Con la llegada de las Brigadas Internacionales también se popularizaron otros himnos del movimiento obrero y antifascista internacionales: Himno del primero de mayo, Le chant des Partisans... Al mismo tiempo, las regiones históricas rescataron composiciones en sus propias lenguas, algunas de ellas prohibidas, como acto de resistencia. Himnos como Guernikako Arbola o Els Segadores pasaron a la historia como parte del patrimonio sonoro de la Guerra Civil.

Del mismo modo que en el Bando Nacional, los regimientos y batallones republicanos se hicieron en ocasiones con un himno distintivo:

Combatimos porque somos, porque fuimos provocados. Nuestras manos conocían

\footnotetext{
${ }^{15}$ Carlos Palacio. Colección de canciones de lucha. Valencia. 1939. Citado en http://www.altavozdelfrente.tk (última consulta 17-02-2005).
} 


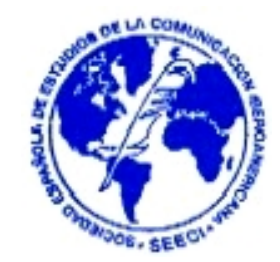

$$
\begin{gathered}
\text { el martillo y el arado. } \\
\text { La República nos puso } \\
\text { el fusil entre las manos. } \\
\text { Por España libertada } \\
\text { mi fusil republicano. }
\end{gathered}
$$

Somos de la sexta, sexta división.

Para los hermanos nuestro corazón.

Muerte, muerte y muerte para la invasión.

Somos de la sexta sexta división ${ }^{16}$

Pese a esta diversidad de composiciones, ninguna de ellas fue considerada el himno representativo de un bando tan heterogéneo como el republicano. A pesar de ello se puede considerar de interés el Himno e Riego por su continua presencia, tanto con su letra original como con las variaciones de origen popular.

Esta composición fue utilizada como blanco de burlas para denostar al bando fiel a la república. Así, pese a no considerarse un himno identificativo - en senso estricto- de todos los colectivos que combatían tras la bandera tricolor, sí se puede considerar un símbolo del republicanismo y, como tal, se utilizaba para vituperar y denigrar a ese bando.

\section{El cancionero de la Guerra Civil. Principales líneas temáticas}

Los cancioneros de la Guerra Civil española de 1936 recogen composiciones heterogéneas tanto si se atiende a su origen como desde el punto de vista temático. En efecto, dichas canciones versan sobre una cantidad de cuestiones diferentes que van desde las hazañas de la guerra hasta la más absoluta cotidianidad, desde composiciones a la muerte hasta otras de tipo de romántico, etc. Una diversidad temática que resulta comparable a la de las épocas de paz.

\footnotetext{
${ }^{16}$ Fragmento del Himno de la Sexta División.
} 


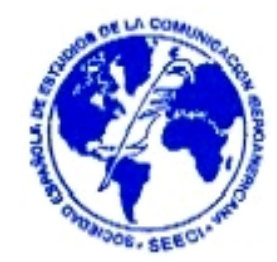

Tras realizar una aproximación a alrededor de trescientas composiciones recogidas por autores de referencia (Díaz de Viana, 1986; Bullón de Mendoza y De Diego, 2000), cancioneros revolucionarios, cancioneros populares, cancioneros web (http://www.altavozdelfrente.tk, http://www.rumbos. net/cancionero,

http://www.unamu.org/musica/española/espanola.htm) y en la película Canciones para después de una guerra (Martin Patino, 1971), se ha podido establecer la siguiente clasificación temática:

Canciones de regimientos, divisiones y otras agrupaciones militares

Canciones de contenido político

Canciones nacionalistas

Canciones patrióticas

Canciones que relatan acontecimientos bélicos

Canciones con personajes

Canciones de contenido cotidiano

Canciones de contenido amoroso

Canciones de contenido religioso

Canciones sobre las madres

Canciones sobre las mujeres

Canciones sobre la muerte

\subsection{Canciones de regimientos, divisiones y otras agrupaciones.}

Tanto los diferentes cuerpos del ejército, como los diferentes grupos militarizados se hicieron con una canción distintiva:

Combatimos porque somos, porque fuimos provocados. Nuestras manos conocían el martillo y el arado. La República nos puso 


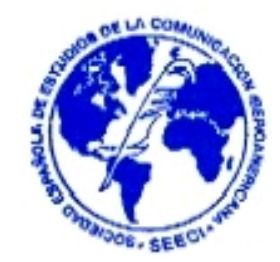

$$
\begin{gathered}
\text { el fusil entre las manos. } \\
\text { Por España libertada } \\
\text { mi fusil republicano. }
\end{gathered}
$$

Somos de la sexta, sexta división.

Para los hermanos nuestro corazón.

Muerte, muerte y muerte para la invasión.

Somos de la sexta sexta división ${ }^{17}$.

En otros de los casos, las composiciones dedicadas a determinadas unidades ya no son himnos sino composiciones populares muy breves en las que se hace referencia a un determinado batallón, división o unidad:

$$
\begin{gathered}
\text { Dinamiteros de Carrasco } \\
\text { somos los más valientes } \\
\text { destrozamos al enemigo } \\
\text { y seguimos para delante... }{ }^{18}
\end{gathered}
$$

\subsection{Canciones de contenido político.}

La canción es el medio idóneo para dar a conocer las motivaciones políticas de cada uno de los bandos. Autores como Bullón de Mendoza y de Diego (2000, p. 266) afirman que es más común la presencia de contenido político en las canciones del Bando Republicano que en las del Nacional. Situación que puede estar relacionada con el hecho de que la movilización de la población civil, que tuvo lugar en el bando fiel a la República, hacía preciso explicar las motivaciones de lucha.

\footnotetext{
${ }^{17}$ Fragmento del Himno de la Sexta División.

${ }^{18}$ En Bullón de Mendoza y De Diego, 2000, pág. 245.
} 


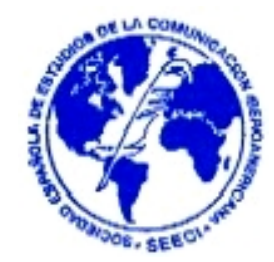

Un ejemplo de una canción del Bando Republicano con gran contenido político es Hijos del Pueblo.

$$
\begin{gathered}
\text { Hijo del pueblo, te oprimen cadenas, } \\
\text { y esa injusticia no puede seguir; } \\
\text { si tu existencia es un mundo de penas } \\
\text { antes que esclavo prefiere morir. } \\
\text { En la batalla, la hiena fascista. } \\
\text { por nuestro esfuerzo sucumbirá; } \\
\text { y el pueblo entero, con los anarquistas, } \\
\text { hará que triunfe la libertad. }{ }^{19}
\end{gathered}
$$

En algunas ocasiones el contenido se refiere al predominio de una ideología, sobre otra perteneciente al mismo bando de la Guerra. Un ejemplo es la presencia de canciones que ponderaban el comunismo sobre el anarquismo y viceversa en el bando antifranquista.

Un ejemplo son estas dos composiciones que responden a estas ideologías contrarias dentro del aglutinante Republicano:

$$
\begin{gathered}
\text { ¡A vivir como hombres libres; } \\
\text { anarquistas; imponed vuestra moral, } \\
\text { superior a la burguesa, } \\
\text { destruyamos para siempre al capita! }{ }^{20} \\
\text { * } \\
\text { ¡Avancemos! iA la revuelta! } \\
\text { Bandera roja, roja bandera. }
\end{gathered}
$$

\footnotetext{
${ }^{19}$ Versión cantada durante la Guerra Civil, a pesar de que ya existió una canción anterior de a la que hace referencia Palacio "Es uno de tantos himnos que en 1885 se presentaron a la Sección de Música revolucionaria del primer certamen socialista". PALACIO, C. (1939). Colección de Canciones de Lucha. Valencia. Citado en http://www.altavozdelfrente.tk (última consulta $17-$ 02-2005).

${ }^{20}$ Fragmento de Arroja la Bomba.
} 


\author{
¡Avancemos! Que en la revuelta \\ la roja enseña triunfará. \\ La roja enseña triunfará ( $x 3$ ) \\ ¡Viva el Comunismo y la libertad! ${ }^{21}$
}

\title{
4.3. Canciones de nacionalistas.
}

En los cancioneros del bando republicano se incluyen algunas composiciones de las denominadas "regiones históricas", a quien la República les había reconocido - de algún modo- su autonomía. Entre estas composiciones destacan himnos como Os Pinos, Els segadors o Gernikako arbola, todas ellas en su idioma original.

$$
\begin{aligned}
& \text { Os tempos son chegados } \\
& \text { dos bardos das edades } \\
& \text { que as vosas vaguedades } \\
& \text { cumprido fin terán; } \\
& \text { pois, donde quer, xigante } \\
& \text { a nosa voz pregoa } \\
& \text { a redenzón da boa } \\
& \text { nazón de Breogán } 22
\end{aligned}
$$

En las canciones del Bando Nacional esta tipología de canciones no tiene correspondiente.

\subsection{Canciones patrióticas.}

\footnotetext{
${ }^{21}$ Fragmento de Bandera Roja (Bandiera Rossa).

22 Fragmento de Os Pinos.
} 


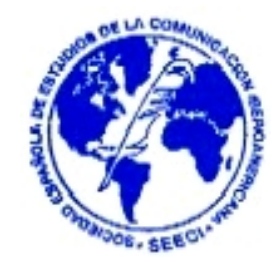

Más habituales en el caso del Bando Nacional, las canciones españolistas glorifican el valor de España como patria. Muchos de los ideales ensalzados y continuamente repetidos por el franquismo en su propaganda tienen tintes claramente españolistas. Su propia consigna "Una, grande y libre" es puro ensalzamiento españolista ${ }^{23}$. Sin embargo, aunque raras veces, también se puede observar este tipo de temática en las canciones del Bando Republicano.

"Dada la enorme disparidad ideológica existente dentro del Bando Republicano (como también del nacional, no los olvidemos), también hay canciones españolistas:

Por una España grande su sangre dio Galán y ahora el Estatuto la quiere desmembrar. catalanes, por qué esa locura que queréis obstinados decir, si esta España es la España de todos desde aquella jornada de Abril" 24

\subsection{Canciones que relatan acontecimientos bélicos.}

Debido a que la canción constituye un relevante vehículo de propaganda, resulta habitual que las hazañas bélicas de ambos bandos se cantasen para darlas a conocer al mayor número de oyentes (tanto de su bando como del contrario). Los avances de las tropas, las batallas ganadas, subían la moral en las trincheras y en la retaguardia. Por esta razón no faltan ejemplos en ambos bandos que dejan constancia de algunas de las hazañas bélicas.

\footnotetext{
${ }^{23}$ Se utilizó la palabra españolista siguiendo a Álvaro Bullón de Mendoza, para definir el patriotismo exacerbado y centralista del Bando Nacional que sería continuado durante el Franquismo. Cfr. Bullón de Mendoza y De Diego, 2000.

24 En Bullón de Mendoza y De Diego, 2000, pág. 271.
} 


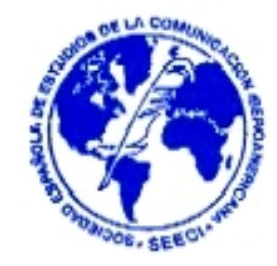

Uno de los hechos mitificados en las canciones de ambos bandos fue la Batalla de Jarama, acontecida entre los días 5 y 25 de febrero. Una batalla, cuya presencia de diversos batallones de las Brigadas Internacionales, dio lugar a diversas composiciones en lenguas extranjeras como Lied der Jarama front o Jarama Valley ${ }^{25}$.

A continuación se presentan dos ejemplos de canciones que tienen como origen dicha batalla. La primera de ellas, nacional, aparece citada en Bullón de Mendoza y De Diego $(2000,234)$; la segunda fue compuesta por los voluntarios del Batallón Lincoln sobre una canción popular estadounidense.

En el sector del Jarama

allí hay muchos cañoneros

ataques todos los días

con tanques y con morteros.

Los rojos se han empeñado

avanzar haciendo fuego.

Pero no se han dado cuenta

que hay aquí hombres con muchos....pechos

There's a valley in Spain called Jarama

It's a place that we all know so well;

It was there that we gave of our manhood

Where so many of our brave comrades fell.

We are proud of the Lincoln Battalion

And the fight for Madrid that it made,

There we fought like true sons of the people

As part of the Fifteenth Brigade.

${ }^{25}$ Cfr. Canciones de las Brigadas Internacionales (1971). Adunar. Buenos Aires. 


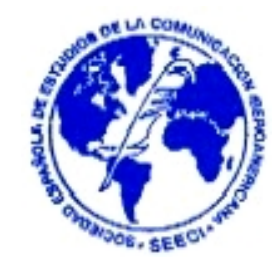

\subsection{Canciones con personajes.}

Otra forma de propaganda fue dar a conocer a los líderes de la contienda o a aquellos personajes que, por diversas circunstancias (fallecimiento, éxitos de guerra, liderazgo popular, etc.) fueron erigidos como héroes de la misma.

Este tipo de composiciones son frecuentes en ambos bandos, al igual que aquellas canciones que ridiculizan a los personajes importantes del bando contrario.

En el Bando Republicano se cita a personajes del Gobierno, además de a héroes populares como a Dolores I bárruri "La Pasionaria", Durruti, "El Campesino" e incluso mitos de movimientos liberales anteriores como Mariana Pineda.

Con Lister, el Campesino,

con Galán y con Modesto

con el comandante Carlos

no hay miliciano, con miedo. ${ }^{26}$

\subsection{Canciones de contenido cotidiano.}

En tiempos de paz resultan frecuentes $s$ aquellas composiciones que versan sobre situaciones habituales y acontecimientos cotidianos. En épocas de conflicto bélico dicha temática sigue repitiéndose, incluyendo alusiones a la vida diaria de una trinchera 0 de la retaguardia. Sin embargo, la cotidianidad en tiempos de guerra presenta más miserias.

Cuando llegué al campamento

qué duro estaba el erial

\footnotetext{
${ }^{26}$ Fragmento de El Quinto Regimiento.
} 


\section{Ahora, sí, duermo en el suelo como cualquier animal... ${ }^{27}$}

O el Sin Pan, canción popular del s.XIX cantada en la Guerra Civil.

$$
\begin{gathered}
\text { Sin pan, sin pan, sin pan } \\
\text { sin pan, sin pan, sin pan } \\
\text { sin pan, sin pan, sin pan } \\
\text { y trabajar. }{ }^{28}
\end{gathered}
$$

\subsection{Canciones de contenido amoroso.}

Un número importante de las composiciones de ambos bandos tienen un trasfondo romántico. Esta temática, que en muchas canciones se presenta como secundaria, se repite en de ambos bandos.

Un ejemplo es la de los Los cuatro muleros, canción del Bando Republicano a la pertenece el siguiente fragmento.

$$
\begin{gathered}
\text { De los cuatro muleros, } \\
\text { que van al agua, } \\
\text { el de la mula torda, } \\
\text { me roba el alma. } \\
\text { De los cuatro muleros, } \\
\text { que van al río, } \\
\text { el de la mula torda, } \\
\text { es mi marío. }
\end{gathered}
$$

A qué buscas la lumbre

$$
\text { la calle arriba }
$$

\footnotetext{
${ }^{27}$ Canción que Díaz de Viana sitúa en el Bando Nacional. Díaz de Viana, 1986, p. 170

${ }^{28}$ Fragmento presente en http://www.altavozdelfrente.tk (última consulta 17-02-2005).
} 


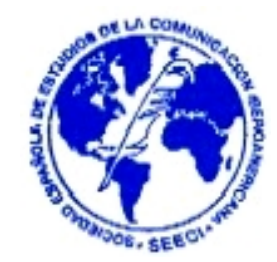

\author{
si de tu cara sale \\ la brasa viva.
}

\title{
4.9. Canciones de contenido religioso.
}

Un tipo de canciones que resultó más habitual en el Bando Nacional debido a que, el anticlericalismo presente en algunos de los colectivos que formaban parte del Bando Republicano, los convirtió en los abanderados de una nueva cruzada religiosa (Bullón de Mendoza y De diego, 2000, pp. 243-244).

Algunos de sus símbolos, enunciados en sus canciones, estaban relacionados con la Iglesia Católica bien de forma directa, como Santiago Matamoros y la Virgen del Pilar, bien indirecta como los Reyes Católicos.

\author{
Pilar bendito \\ Fuente de gloria \\ danos la victoria \\ gracias y alabanzas al cantar \\ a la Virgen del Pilar. ${ }^{29}$
}

Si embargo, pese a que algunos de los grupos que formaban el Bando Republicano eran profundamente anticlericales, no faltan ejemplos de coplillas populares con contenido religioso. Algunas de estas canciones religiosas de la zona republicana utilizaban símbolos del bando contrario como la siguiente composición recogida por Bullón de Mendoza y De Diego (2000, p. 273)

\footnotetext{
${ }^{29}$ En Bullón de Mendoza y De Diego, 2000, pág. 243.
} 


\section{La Virgen del Pilar dice \\ que no quiere ser fascista \\ que quieres ser patrona \\ de las tropas socialistas}

\subsection{Canciones sobre las madres.}

Otro de los recursos temáticos más repetidos en estas canciones es el de la madre. Ambos bandos presentan composiciones en la que madre aparece esbozada como apoyo del soldado que tiene que marcharse al frente o de aquel que, en el fragor de la batalla, hecha de menos su realidad cotidiana o teme por su vida.

Un ejemplo es la composición, con letra de Miguel Hernández, La guerra madre, la guerra $^{30}$. Canción que refleja esa añoranza confrontada con la realidad de la contienda.

La guerra, madre la guerra.

Mi casa sola y sin nadie.

Mi almohada sin aliento.

La guerra, madre: la guerra.

Mi almohada sin aliento.

La guerra, madre: la guerra.

Republicanos y Nacionales mitificaron la figura de la madre como elemento propagandístico hasta el punto de convertirse en heroína por "ceder" sus hijos a la causa. En otros casos como en las coplas populares construidas más allá e cualquier recurso propagandístico, la lucha fraticida queda patente en el dolor de la madre (Bullón de Mendoza y De Diego, 2000, p. 248):

\footnotetext{
${ }^{30}$ Hernández, M. (1989). Viento del Pueblo. Madrid, Cátedra. Págs. 165-166.
} 


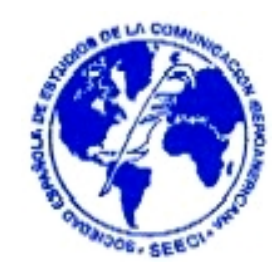

\begin{abstract}
Tengo un hijo con los rojos
$Y$ otros con los nacionales

Los dos están tirando tiros

¿por quién suspira la madre?
\end{abstract}

\title{
4.11. Canciones sobre las mujeres.
}

Durante la Guerra Civil, con los hombres en el frente, la mujer adoptó un papel más activo que la llevó a ocupar un importante lugar en la organización de ambos bandos. Por esta razón es habitual que existan composiciones que ensalcen su participación en la guerra o que les muestren como han de comportarse en su día a día, dentro del nuevo orden social establecido.

Ejemplos de esta guía de comportamiento cantada encontramos en el Bando Nacional, en cuyo cancionero se encuentra esta canción recogida por Díaz de Viana (1986, pág. 166).

Ha de ser la mujer

de la España Imperial

un sol de amanecer

con calor de ideal.

Forjadora de hogar,

santuario de amor,

heroína sin par

de su honor.

Española y mujer

de la patria calor

y mi vida ha de ser

mitigar el penar

dondequiera que esté;

cumplidora leal 


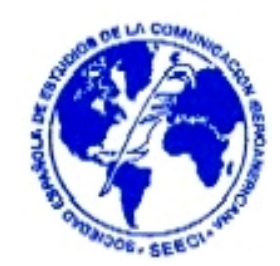

$$
\begin{aligned}
& \text { del sagrado deber } \\
& \text { de virtud sin igual } \\
& \text { ¡Ante todo mujer!! } \\
& \text { Agustina en valor } \\
& \text { Isabel en la paz }
\end{aligned}
$$

En el Bando Republicano se hizo célebre A las mujeres, canción que trata de arengar a la mujer para que colaborase en la revolución contra los tiranos y la explotación.

\author{
Debéis las mujeres colaborar, \\ en la hermosa obra de la humanidad; \\ mujeres, mujeres, necesitamos vuestra unión \\ el día que estalle nuestra grande revolución. \\ Hermanas que amáis con fe la libertad \\ habéis de crear la nueva sociedad... \\ El sol de gloria que nos tiene que cubrir \\ a todos en dulce vivir. \\ Por una idea luchamos, \\ la cual defendemos \\ con mucha razón. \\ Se acabarán los tiranos, \\ guerras no queremos \\ ni la explotación.
}

Otras coplillas a las que Bullón de Mendoza y De Diego (2000, p. 280) aluden como de color político inseguro y que, por la presencia de la mujer en las trincheras o la invitación a luchar en el frente, podrían situarse en el Bando Republicano son las siguientes. 


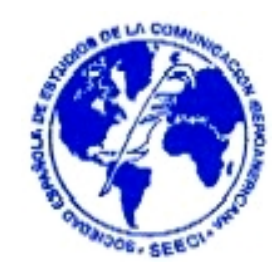

¡Ay que ver a las asturianas

metidas en las trincheras

con el cigarro en la boca

cargadas de cartucheras!

Chiquilla bonita, serrana morena, quiero que vengas conmigo a la guerra.

$A$ la guerra no, no quiero ir, que muchos peligros me esperan allí.

La siguiente composición del Bando Nacional sobre las milicianas supone un interesante testimonio; al tener constancia de que era una canción que cantaban las franquistas presas en Madrid.

\author{
Milicianas de bando criminal \\ que las pistolas nos suelen enseñar \\ y nos hacen barrer las escaleras \\ y a todo trance nos quieren humillar. \\ Ay, milicianas faroleras \\ cuánto nos quieres humillar \\ porque llevamos en las venas \\ sangre española de verdad.
}

Finalmente también se puede destacar el himno de Mujeres Libres, como un alegato de la mujer y de la revisión de su papel en la sociedad.

Puño en alto mujeres de Iberia

hacia horizontes preñados de luz

por rutas ardientes,

los pies en la tierra

la frente en lo azul. 


\author{
Afirmando promesas de vida \\ desafiamos la tradición \\ modelemos la arcilla caliente \\ de un mundo que nace del dolor \\ ¿Que el pasado se hunda en la nada! \\ ¿Qué nos importa del ayer! \\ Queremos escribir de nuevo \\ la palabra MUJER \\ Puño en alto mujeres del mundo \\ hacia horizontes preñados de luz, \\ por rutas ardientes \\ adelante, adelante, \\ de cara a la luz. ${ }^{31}$
}

\title{
3.12. Canciones sobre las muerte
}

Algunas veces como tema principal y otras tantas como tema secundario, la muerte estuvo presente en las canciones de ambos bandos. Esta muerte suele aparecer personificada por una mujer, que en algunas ocasiones llega a tener nombre propio.

"La muerte puede ser, sin duda, un tema tremendo, pero entre los combatientes del Frente de Madrid llegó a ser algo tan frecuente que, familiarmente se llamaba 'la Pepa'; y a 'la Pepa'l os republicanos españoles le cantaban, en las cárceles, con todo desparpajo estos escalofriantes versos:

Y es la Pepa una "gachi" que está de moda en Madrid.

Que "tié" predilección por los "rojillos"

\footnotetext{
31 Compuesto por Lucía Sánchez Saornil en 1937. Ackelsberg, M. (1999). Mujeres libres. El anarquismo y la lucha por la emancipación de las mujeres. Virus. Barcelona.
} 


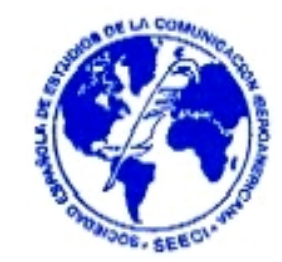

Cuando viene esta mujer

De Torrijos a Porlier

Y al más bravo se le arruga el solomillo.

¡Pepa! ¡Pepa!

Dónde vas con tanto tío.

$$
\text { ¡Pepa! ¡Pepa! }
$$

Te estás metiendo en un buen lío.

Como sigas de este modo sin parar

Quedará Madrid vacío

$Y$ nos vas a jorobar.

La música que acompañaba a semejante texto era "achulada" y de "chotís", en consonancia con las estrofas, pues la "Pepa" esa "gachi", debía ser cantada y jaleada como tal." (Díaz de Viana, 1986, p. 69).

Una de las composiciones más famosas, cantada durante este período es Novio de la muerte. Canción cuya relevancia la ha llevado a ser considerada como el himno de la Legión.

Soy un hombre a quien la suerte

hirió con zarpa de fiera.

Soy un novio de la muerte

que va a unirse en lazo fuerte

con tal leal compañera.

Más allá de su imagen de mujer, la muerte aparece nombrada con naturalidad en las canciones de ambos bandos. Es el caso, por ejemplo, de la republicana Las compañías de acero 


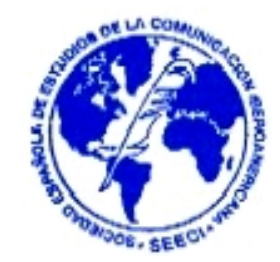

¡Las Compañías de Acero,

cantando a la muerte van!

iSu fuerza es mucha

y van a la lucha por la libertad!...

Una muerte que puede ser mentada de manera directa, como en el ejemplo anterior, o con mayor sutileza como sucede en Canto nocturno de las trincheras donde aparece de forma velada en los versos "brota sangre del obrero/ para un futuro mejor".

\section{La contrapropaganda.}

En muchas ocasiones las canciones no sólo eran vehículos propagandísticos de una determinada ideología. Algunas de las composiciones, particularmente aquellas menos cultas, solían incorporar alusiones ofensivas a la simbología del bando contrario.

En este sentido, Bullón de Mendoza y De Diego (2000) y Díaz de Viana (1986), se refieren a numerosas coplillas, fruto de la recogida oral, que por su carácter popular y su origen espontáneo están ausentes en otro tipo de cancioneros "oficiales".

Si eres del puño cerrado

escucha este fandanguillo

me cago en 10 "colorao"

en la hoz y en el martillo

ó

General Queipo de Llano

que siempre ha sido un canalla

está refugiado en Sevilla 


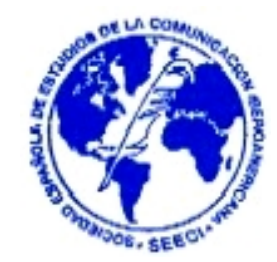

para perder a media España. ${ }^{32}$

Esta fórmula, muy común, a la que se ha denominado contrapropaganda se suele manifestar de dos maneras diferentes. La primera de ellas, más sencilla, es la de aludir en las letras de las canciones a símbolos y personajes del otro bando con afán denigratorio.

Es el caso, por ejemplo de la canción El tren blindado

$$
\begin{gathered}
\text { Yo me fui en el tren blindado } \\
\text { camino de Andalucía } \\
\text { y vi que Queipo de Llano } \\
\text { al verlo retrocedía. } \\
\text { Anda jaleo, jaleo, jaleo, } \\
\text { silba la locomotora } \\
\text { y Queipo se va a paseo } \\
\text { y Queipo se va a paseo. }{ }^{33}
\end{gathered}
$$

La segunda, más elaborada, consiste en utilizar la base musical de un himno enemigo para construir una nueva letra que ridiculice su ideología o sus héroes; escarnio que alcanza una mayor entidad al utilizar como vehículo uno de los símbolos más identificativos.

Es, precisamente, esta segunda manifestación a la que se prestará mayor atención dado su valor como elemento de contrapropaganda

Este tipo de canciones, que han sido denominadas de contrapropaganda, suponen variaciones de letras de composiciones con un algo grado de simbolismo para alguno

\footnotetext{
32 En Bullón de Mendoza y De Diego, 2000, pág. 248 y pág. 274.

${ }^{33}$ Canción que hace referencia al tren blindado donde iban los tres generales más odiados: Mola, Franco y Queipo de Llano.
} 


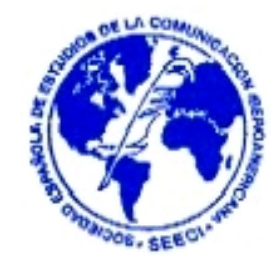

de los colectivos contendientes, con el único fin de denostarlos. Una ofensiva, habitual en ambos bandos, que sirvió en múltiples ocasiones para minar y destruir algunos de los símbolos relevantes de la ideología contraria, al tiempo que recordaba los fracasos bélicos del enemigo.

La propia utilización de los himnos, distintivos de ideologías o determinadas colectividades, como objeto de mofa constituía un modo de atentar contra aquellas personas que se sentían identificadas por dicha composición. Una utilización que fue aprovechada popularmente como una forma más de ataque al enemigo.

El mejor ejemplo de esta tipología de composiciones de contrapropaganda lo tenemos en el Himno de Riego. Un himno que ha sido utilizado como base melódica para numerosas letrillas populares de sátira hacia los republicanos y sus símbolos, en particular a dicha composición, además de valerse de su popularidad para transmitir un mensaje contrapuesto a la finalidad última de este himno ${ }^{34}$.

La extensión de estas letrillas satíricas durante la Guerra Civil y en los primeros años del Franquismo fue tal que, inclusive, llegaron a impregnar las canciones infantiles. En Galicia, según algunas de las fuentes orales recogidas, fue muy común esta versión de carácter escatológica del Himno de Riego:

\footnotetext{
bando como el clásico

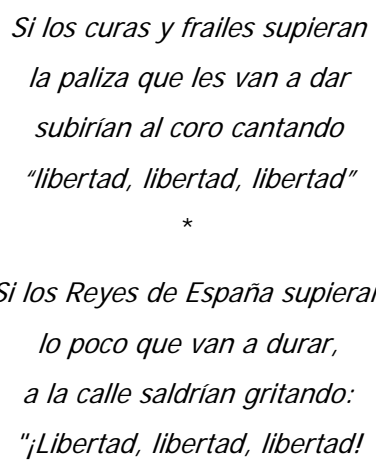

${ }^{34}$ El propio Bando Republicano creó letrillas populares con la música de este himno para ridiculizar a los "enemigos" de este 


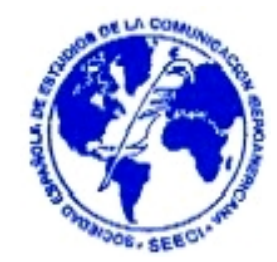

Un hombre estaba cagando

$$
\begin{gathered}
\text { y no tenía papel } \\
\text { pasó por allí Azaña } \\
\text { y limpió el culo con el. } \\
\text { ¡Ay! que cochinos, iay! que marranos } \\
\text { iay! que cochinos los republicanos. }{ }^{35}
\end{gathered}
$$

En el Bando Nacional, himnos como el Cara al sol o el Oriamendi, sufrieron la misma suerte que el Himno de Riego, al ser vituperados por el Bando Republicano ${ }^{36}$.

Del Oriamendi, por ejemplo, se ha tenido acceso a una versión con un origen un tanto confuso; dos autores de referencia han citado esta variación con diferentes procedencias. Bullón de Mendoza y De Diego se refieren a ella como una letrilla de los falangistas para molestar a sus compañeros de lucha (2000, p.240), mientras que Díaz de Viana vincula dicha letrilla al Bando Republicano e incluso a una situación concreta (1986, p. 131):

\footnotetext{
35 Muy similar por el contenido, pero de ideología diferente es esta otra letrilla antimonárquica recogida en Bullón de Mendoza y De Diego (2000, pág. 272).
}

\author{
La República estaba cagando \\ y no tenía papel, \\ cogieron a Alfonso XIII \\ y se limpiaron con él.
}

\begin{abstract}
${ }^{36}$ Los himnos del Bando Nacional no sólo fueron ridiculizados por el Bando Republicano. El conflicto entre dos de los grupos presentes en este bando, tradicionalistas y falangistas, terminó con intercambios de letras satíricas. "Cierto es que los falangistas no se limitaban a adaptar para uso propio las canciones tradicionalistas, sino que en ocasiones lo hacían con el deliberado propósito de molestar a sus compañeros de armas (...)" Bullón de Mendoza y De Diego, Opus Cit. pág. 240. Un ejemplo es la siguiente:
\end{abstract}

\author{
Antes éramos rojillos \\ ahora requetés, \\ y si se vuelve la tortilla \\ comunistas otra vez.
}


"En la zona republicana, este canto sería objeto de jocosa réplica; cuando, ya vencidos los que habían combatido por la República, se vieron obligados a cantar en los patios de las cárceles el Oriamendi, tal invento de la letra cambiada serviría de íntimo consuelo a muchos de ellos. La apariencia de lo que se oía resultaba igual que si entonaran la letra ortodoxa, pero su significado era bien distinto:

\author{
Por Dios y la pata del Buey \\ lucharon vuestros padres; \\ por Dios, por la pata del Buey \\ lucharéis vosotros también. \\ Si tu padre se tirara \\ desde lo alto de un balcón \\ tú también te tirarías \\ por seguir la tradición." 37
}

Con el caso del Cara al so/sucedió algo similar que con el Oriamendi, a pesar de que el hecho de ser el máximo identificativo musical del Bando Nacional ( y durante muchos años) lo hizo más vulnerable a las críticas del Bando Republicano (y de los propios tradicionalistas). Algunas variaciones populares de origen antifranquista que se han realizado de este himno son:

Cara al sol con la camisa vieja

que tú robaste a un rojo ayer...

ó

Cara al sol, al sol que más calienta me puse el "mono" antes de ayer me hallará la muerte si me pesca 


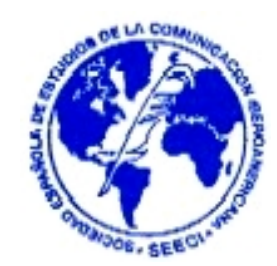

\author{
sentado en el café 38 \\ ó \\ Cara al sol, al sol que más calienta \\ sentada alegre en el café \\ me hallarás si vienes a verme...
}

Del mismo modo que los fascistas con el Oriamendi, no faltaron réplicas tradicionalistas del Cara al so/con letrillas satíricas. Una de ellas es la que sigue:

Cara al sol con la camisa vieja

que tú bordaste Don Javier,

no me importa que el flecha no me quiera,

me quiere el requeté.

El requeté me compra caramelos

$Y$ me lleva al cine cuando quiero.

Arriba España a vencer,

que me caso con el requeté 39 .

En definitiva, este tipo de composiciones que han sido denominadas de contrapropaganda suponen otro modo de extender una ideología que, en lugar de enunciar en positivo aquellos elementos sobre los que se fundamenta (valores, hazañas, héroes, etc.), vitupera los símbolos del contrario (sea éste el enemigo real u otro colectivo del mismo bando con el que mantiene una lucha por el poder) con la intención de reafirmarse a través del rechazo hacia un posicionamiento concreto.

\footnotetext{
${ }^{38}$ En Díaz de Viana, Opus Cit. pág. 138.

39 Bullón de Mendoza y De Diego, 2000. pág.241.
} 


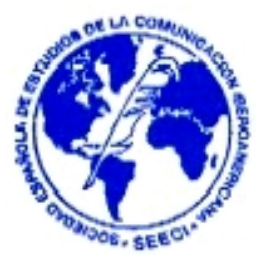

\title{
6. A modo de conclusión.
}

Como se ha tratado a lo largo de estas páginas, la función de la canción como arma fue constante durante la Guerra Civil e, incluso, una vez acabada ésta ${ }^{40}$.

Ambos bandos se valieron de múltiples composiciones, de múltiples orígenes y temáticas, para transmitir su ideología en un contexto en el que serían impensable otras formas de propaganda. Vehicular diferentes ideas, símbolos, y hazañas por medio de la música permitió un mayor recuerdo al tiempo que propició, sobre todo en el caso de los himnos, la identificación del sujeto a un determinado colectivo (por ejemplo, a un batallón).

Esta necesidad de arengar a las tropas propias y dar a conocer los símbolos de cada uno de los bandos entre la población fue siempre pareja a la de criticar los atributos, personajes y actuaciones en la Guerra del bando contrario. Función que ha sido denominada de contrapropaganda y que, en esencia, se trataba de otro modo de buscar la adhesión a una causa concreta (precisamente contraria a la que se referían).

\footnotetext{
${ }^{40}$ En los primeros años de la Posguerra española se popularizó, gracias a su constante presencia en la radio, el pasodoble Ya hemos pasao, interpretado por Celia Gámez. Este pasodoble de Manuel Talavera, musicado por Cotarelo, se regodeaba en el "no pasarán" republicano.
}

\author{
No pasarán, decían los marxistas \\ No pasarán, gritaban por las calles, \\ No pasarán, se oía a todas horas \\ Por plazas y plazuelas por voces miserables, \\ ¡No pasarán! \\ Ya hemos paso, decimos los facciosos, \\ Ya hemos paso, gritamos los rebeldes \\ Ya hemos paso y estamos en el Prado \\ Mirando frente a frente a la señá Cibeles
}

¡Ya hemos pasao! 


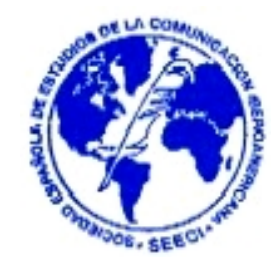

Hoy, cuando una gran parte de las canciones de la Guerra Civil se perdieron con sus protagonistas, la escucha de aquellas composiciones que todavía se conservan no sólo suponen una interesante fuente para la historiografía, sino una de las manifestaciones más emotivas de una manera de ser, de pensar, de actuar.

\section{Bibliografía.}

ABELLA, R. (2005). La vida cotidiana durante la Guerra Civil. Barcelona, Planeta.

ACKELSBERG, M. (1999). Mujeres libres. El anarquismo y la lucha por la enmancipación de las mujeres. Virus. Barcelona.

BROWN, J.A.C. (1991). Técnicas de persuasión. Alianza Editorial. Madrid.

BULLÓn DE MENDOZA, A.y DE DIEGO, A. (2000). Historias orales de la Guerra Civil. Ariel. Barcelona.

Cancionero libertario (197?). CNT (en biblioteca de Universidad de Santiago de Compostela).

Cancionero popular español (1968). Almenar. Madrid.

Cancionero popular Español (1974). Delegación Nacional de la Sección Femenina del Movimiento. Madrid.

Cancionero revolucionario (?). Barcelona, España Federación Local de Barcelona. (en biblioteca de Universidad de Santiago de Compostela).

Cancionero revolucionario (1977). CNT. Burdeos.

Canciones de las Brigadas Internacionales (1971). Adunar. Buenos Aires.

Dí AZ DE VIANA, L. (1986). Canciones populares de la Guerra Civil. Taurus. Madrid.

DOMENACH, J. M. (1963). Propaganda política. Barcelona, 62. 


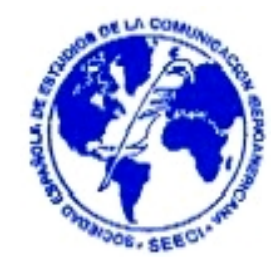

FONSECA, C. (2005). Trece rosas rojas. Temas de Hoy. Madrid.

FRASER, R. (1979). Recuérdalo tú y recuérdalo a otros. Historia oral de la Guerra Civil Española. Crítica. Barcelona.

GARCíA LORCA, F. (1994). Romancero Gitano. Cátedra. Madrid.

GIL, B. (1964). Cancionero infantil (antología). Taurus. Madrid.

HERNÁNDEZ, M. (1989). Viento del pueblo. Cátedra. Madrid.

JIMÉNEZ MILLAR, A. (2001). Promesa y desolación: el compromiso en los escritores de la Generación del 27. Universidad de Granada. Granada.

MARTÍN PATINO, B (1971). Canciones para después de una guerra. 1971 (película).

NASH, M. (1999). Rojas, las mujeres republicanas en la Guerra Civil. Taurus. Madrid.

PIZARROSO QUINTERO, A. (1993). Historia de la propaganda. Eudema. Madrid.

RODRÍGUEZ PUÉRTOLAS, J. (Coord.) (1978-1979) Historia social de la literatura española en lengua castellana. Castalia ( vol.I y II). Madrid.

\section{Webgrafía.}

http://www.altavozdelfrente.tk

http://www.guerracivil1936.galeon.com/canciones

http://www.la-moncloa.es/Espana/ElEstado/simbolos/elhimno.htm

http://www. rumbos.net/cancionero

http://www.unamu.org/musica/española/espanola.htm 